\title{
MORPHOANATOMY, HISTOCHEMISTRY AND CRYSTALS OF THE UNDERGROUND SYSTEM OF BACCHARIS NOTOSERGILA (Asteraceae)
}

\author{
MORFOANATOMÍA, HISTOQUÍMICA Y CRISTALES DEL SISTEMA SUBTERRÁNEO DE \\ BACCHARIS NOTOSERGILA (ASTERACEAE)
}

\author{
Alejandra V. Carbone ${ }^{1} \mathbb{D}$, Federico E. Fernández ${ }^{2} \mathbb{D}$, Marcelo P. Hernández ${ }^{3}(\mathbb{D}$ \\ and Ana M. Arambarri ${ }^{*}$ ii
}

1. Instituto de Fisiología Vegetal (INFIVE), La Plata, Buenos Aires.

2. Forrajicultura y Praticultura, Facultad de Ciencias Agrarias y Forestales (FCAyF), Universidad Nacional de La Plata (UNLP).

3. Sistemática II, Facultad de Ciencias Naturales y Museo, UNLP. 1,3,4. Área de Botánica, FCAyF, UNLP, 60 y 119, C. C. 31 (1900) La Plata, Argentina.

*anaramba@yahoo.com.ar

\section{Citar este artículo}

CARBONE, A. V., F. E. FERNÁNDEZ, M. P. HERNÁNDEZ \& A. M. ARAMBARRI. 2019. Morphoanatomy, histochemistry and crystals of the underground system of Baccharis notosergila (Asteraceae). Bol. Soc. Argent. Bot. 54: 519-532.

DOI: http://dx.doi. org/10.31055/1851.2372.v54. n4.24930

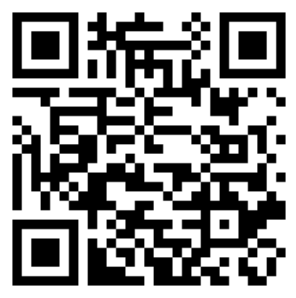

Recibido: 17 Julio 2019 Aceptado: 15 Octubre 2019 Publicado: 15 Diciembre 2019 Editora: Ana María Gonzalez (D)

ISSN versión impresa 0373-580X ISSN versión on-line 1851-2372

\section{SUMMARY}

Background and aims: Baccharis notosergila is presented as a productivity-reducing weed in the fields of the Salado river basin, Buenos Aires, Argentina. The aims of this work were: to describe the structure of the underground system, the origin of sprouts, locate the secretory structures and storage substance to understand the adaptation strategies of this species as well as its ability to withstand chemical and mechanical control.

M\&M: The collected material was examined with conventional optical microscopy techniques. Histochemical tests to identify secondary metabolites were performed, and crystals were analyzed by a scanning electron microscope.

Results: The subterranean system found was a xylopodium which has high shoot bud-forming potential. Storage substance was found to be inulin. Test for starch was negative. Resins and lipids (oil drops) were identified in ducts of roots; tannins and crystals of calcium oxalate were also found in the xylopodium and roots.

Conclusions: The presence of these characteristics on the underground systems could explain the frequency of this species in the floristic from Salado river basin in which alternate periods of high humidity and drought. The belowground bud bank would be important to $B$. notosergila survival in this area with extreme climatic factors, and its resistance to mechanical and chemical control. Understanding the anatomical features of these plants is one of the steps to appropriate management of this species in the Salado river basin.

\section{KEY WORDS}

Buds, inulin, roots, Salado river basin, xylopodium.

\section{RESUMEN}

Introducción y objetivos: Baccharis notosergila es una maleza de alta incidencia que reduce la productividad en campos de la Depresión del Salado, Buenos Aires, Argentina. Los objetivos de este trabajo fueron: describir la estructura del sistema subterráneo, el origen de los brotes y localizar las estructuras secretoras y la sustancia de almacenamiento, para comprender las estrategias de adaptación de esta especie, así como su capacidad para resistir el control químico y mecánico.

M\&M: El material recolectado fue analizado con técnicas convencionales de microscopía óptica; se realizaron pruebas histoquímicas para identificar los metabolitos secundarios y se analizaron los cristales con microscopio electrónico de barrido.

Resultados: El sistema subterráneo encontrado fue del tipo xilopodio, el cual tiene un alto potencial de formación de brotes. Como sustancias carbonadas de almacenamiento se encontró inulina; no hallándose almidón. En los conductos secretores de las raíces se identificaron resinas y aceites; también se hallaron taninos y cristales de oxalato de calcio en el xilopodio y las raíces.

Conclusiones: La presencia de estas características en los sistemas subterráneos podría explicar la elevada frecuencia de esta especie en la composición florística de la cuenca del río Salado, en la que alternan períodos de alta humedad y sequía. El banco de yemas subterráneas sería importante para la subsistencia de $B$. notosergila en esta área con condiciones climáticas extremas y también su tolerancia al control químico y mecánico. Comprender las características anatómicas de estas plantas es uno de los pasos para el manejo adecuado de esta especie en la cuenca del río Salado.

\section{Palabras clave}

Depresión del Salado, inulina, raíces, xilopodio, yemas. 


\section{INTRODUCTION}

The Salado river basin situated in Buenos Aires province (Argentina) is a plane with predominance of saline and alkaline soils and a deficient drainage. This area in $80 \%$ of its surface is occupied by natural prairies (grassland) principally dedicated to livestock farming (Rodríguez \& Jacobo, 2012). Several herbaceous and subshrub species of these prairies have thickened underground systems, frequently rhizomes, exerting a strong competition for water, nutrients and light with the forage value species of the natural prairie, reducing the productivity and receptivity of these environments (Sione et al., 2006). Baccharis notosergila Griseb. (Asteraceae) is a native subshrub aggressive as weed in the Salado river basin (Fig. 1). This species usually enter in dormancy at the end of autumn with senescence of aerial organs, and sprout in the following spring; flowering occurs in summer after a period of vegetative growth in spring-summer. This work is a part of the project that includes studies of subterranean and aerial systems of the $B$. notosergila with the purpose to find the best technique to management of this weed. In a preliminary assay, this species showed to be resistant to chemical control in combination or not with the mechanical control because it sprouted up in the following spring (Urdampilleta, 2019). It is important to highlight that resistant plants are those which have the ability to survive and reproduce after the application of a type normally lethal herbicide dose (Herbicide Resistant Plants Committee, 1998; Puricelli \& Tuesca, 2005).

It is known that many species of Asteraceae have thick underground systems (Cury, 2008; Appezzato-da-Glória \& Cury, 2011), their structures storage reserves, mostly fructans, and have a high capacity of bud formation (Tertuliano \& Figueiredo-Ribeiro, 1993). Alonso \& Machado (2007) and Appezzato-da-Glória et al. (2008a) suggested that bud-bearing underground systems could contribute to the formation of a underground bud bank. It comprises all buds from plants, which can be potentially used for vegetative regeneration by the formation of new shoots after the partial or total removal of aboveground parts caused by diverse extreme

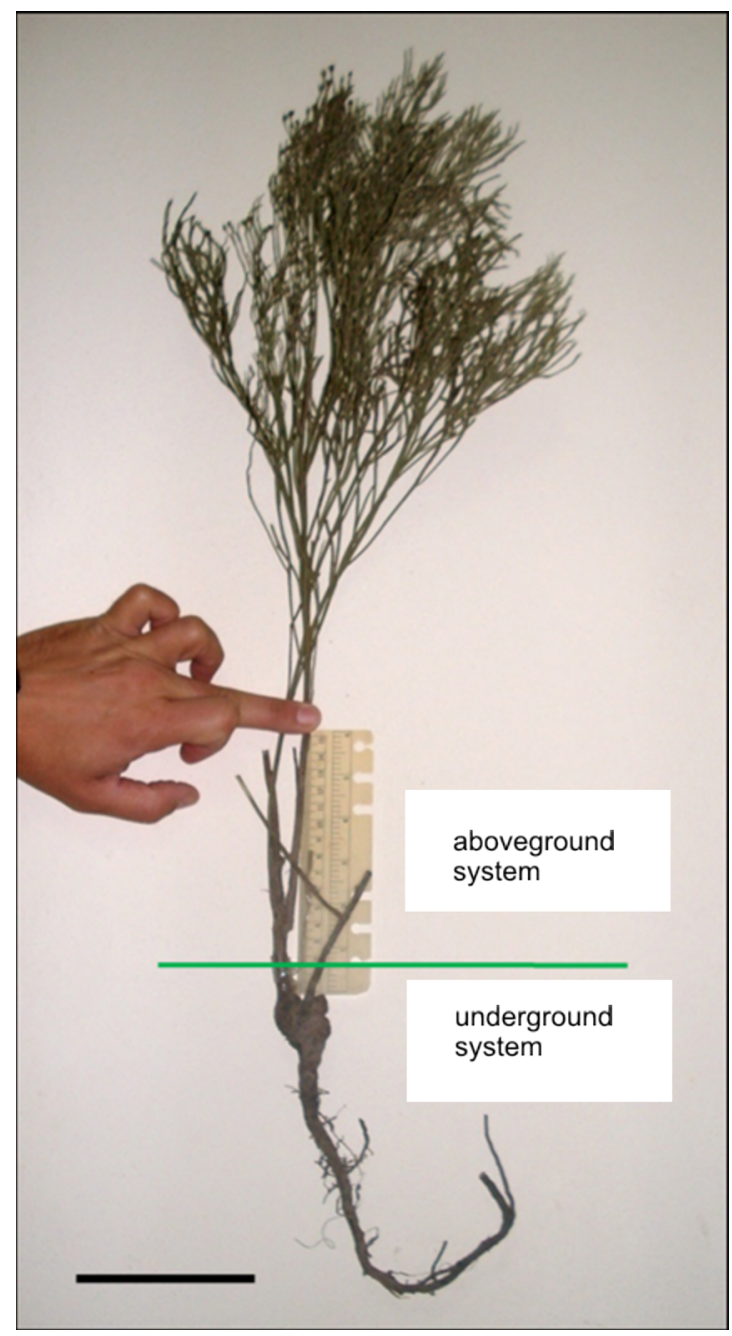

Fig. 1. Parts of Baccharis notosergila respect to the ground level: aerial (aboveground) and subterranean (underground) systems. Scale $=10$ $\mathrm{cm}$.

climatic factors. Frequently, after the death of aboveground biomass, there is an increase in the number of species resprouting from the buds located in underground organs, thus confirming the importance of such bud-bearing organs (Appezzatto-da- Glória et al., 2008a). In Asteraceae, the principal reserve substances are fructans, which have an important role as reserve because they are involved in a number of adaptive strategies in plants subjected to extreme growing conditions (Gomes de Moraes et al., 


\section{A. V. Carbone et al. - Baccharis notosergila: Subterranean system}

2016). As was mentioned above, B. notosergila showed to be a resistant weed to mechanical and chemical control. The introduction and adoption of new alternatives of weed managements require deepen the knowledge about organs and their structures; also to increase the knowledge about storage and secreted compounds, because these characteristics mean adaptation and resistance to environmental conditions, and control treatments. Therefore, the objectives of the present work were: to analyze the underground system type and its structure; establish the origin of sprouts and the presence of secretory structures, and to test for lipid, resin, tannin, and carbohydrate reserves, and finally, to perform an analysis of crystal types and composition using a scanning electron microscope.

\section{Materials and Methods}

During the year 2018, in the months of June, September-October and December, adult plant material of $B$. notosergila were collected from natural populations in "El Amanecer" farm. It is situated in Vieytes, Magdalena department, Buenos Aires province, Argentina. The voucher specimens were deposited in the herbarium of Facultad de Agronomía, National University of La Plata, 17-XII-2018, F. Fernández \& A. Carbone 1, 2, 3, 4 (LPAG). Images of specimens from Instituto de Botánica Darwinion were consulted. ARGENTINA. Prov. Buenos Aires: Pdo. Berazategui, Hudson, 16-IV-1927, Burkart 1302 (SI) (image 15). Prov. Entre Ríos: Dpto. Gualeguaychú, aeródromo, 17-IV-1965, Burkart 25811 (SI) (image 9); Dpto. Gualeguaychú, 8-IV-1963, Burkart 24298 (SI) (image 12); Dpto. Concordia, 31-I-1927, Burkart 1122 (SI) (image 14).

For the anatomical study, samples of six adult plants were fixed in formalin-acetic acid-alcohol $70 \%$ (FAA) (Johansen, 1940). The fixed material was rehydrated in water boiling a total of four hours in two periods of two hours each. Freehand cross and longitudinal sections were cut, bleached in $50 \%$ sodium hypochlorite $(\mathrm{NaOCl})$, washed three times with distilled water, then a successive double staining was performed with Alcian blue and safranin (Luque et al., 1996), on others a metachromatic staining was performed using Cresyl violet $(0,5 \%)$, and also a monochromatic staining was made using alcoholic solution of safranin (80\%) (D'Ambrogio, 1986). The sections were then mounted in gelatin-glycerin on glass slides and sealed with nail polish.

For histochemical analysis, inulin was identified directly on freehand cross-sections of the fixed material, where the spherocrystals were observed. To test lipophilic substances an alcoholic solution of Oil red "O" was used (Gurr, 1971) the red color indicated positive test; detection of phenolic compounds (tannins) was performed using ferric chloride $(10 \%)$ and sodium carbonate (2\%) (Zarlavsky, 2014), a green-blue color was a positive test; starch was identified with Iodine-Potassium-Iodide (IKI) (Ruzin, 1999) a black-blue color indicate positive test. Resins were detected using a saturated solution of copper sulphate (Cosa et al., 2014) a color emerald green indicate positive test. To distinguish if crystals were calcium oxalate and non carbonate or phosphate salt, xylopodium and root bleached sections were immersed in glacial acetic acid (5\%) for $30 \mathrm{~min}$. The persistence of crystals indicated they were of oxalate salt (Yasué, 1969). Morphology of the xylopodium was studied by using a Bausch \& Lomb stereomicroscope and photomicrograps were taken with a Sony DSC-W30 camera. Slides were analyzed with a Nikon E200 LED optical microscope with a video camera attached, and using micrometrics SE Premium software.

Scanning electron microscope (SEM) study was performed using portions of xylopodium and root. They were taken from fixed material, dehydrated in ethyl alcohol $\left(100^{\circ}\right)$ for $24 \mathrm{~h}$ and air dried. Then the samples were affixed on stubs by double-sided adhesive tape and were submitted to metallization with a fine, thin gold layer by means of a cool diode sputter coating procedure. Afterwards they were examined with a Philips 505 SEM, and photographs were taken. The crystal composition was examined by an energy dispersive spectrometer (EDAX DX PRIME 10) to determine the elemental composition of crystals, and the characteristic spectrum of the elements was mapped with the Princeton graphic system. Centro de Investigación y Desarrollo en Ciencias Aplicadas "Dr. Jorge J. Ronco" (CINDECA), 
Consejo Nacional de Investigaciones Científicas y Técnicas (CONICET), Universidad Nacional de La Plata (UNLP).

\section{Results}

Baccharis notosergila has an underground system formed by a xylopodium and a thickened taproot (the primary root), with numerous root branches (secondary roots), and adventitious roots originated from the medial and basal part of the xylopodium. The xylopodium is situated at ground level or some centimeters under it. The size and shape of xylopodium varied according to the age [Figs. 1; 2A, B; images 12, 15 (SI)].

Xylopodium. It is a perennial thickened and woody organ with development periods. It has numerous buds distributed along the axis and high resprout capacity (Fig. 2B). The buds are globose and present numerous initial scaly-leaf primordial (Fig. 2C). They are covered by uni and bi-seriate glandular and non-glandular flagelliform trichomes, all have lipophilic substances, but the glandular containing oil droplets (Fig. 2D). Xylopodia of different diameters were studied, when it was of 2.0-2.5 $\mathrm{cm}$ presented a secondary structure of 2-2.5 years old, and when it was of 3.0-4.0 cm diameter had more than eight years old. Origin of the xylopodium parts were established based on its morphology and anatomy. Xylopodia were sectioned at different levels (Fig. 2B), and caulinar, hypocotyl, and taproot structures forming the woody axis were found. The study of surface view of cross-sections at different level of the xylopodium exhibited the stem, hypocotyl and taproot structures (Fig. 3A).

There are many buds found on the xylopodium that can develop into new stems [Fig. 2B; 3B; image 9 (SI)]. In the lower part (at hypocotyl and taproot level) are also formed more or less thickened adventitious roots [(Fig. 3A, C), images 12 and 14 (SI)].

According our anatomical study a xylopodium of several years old, cross-sectioned at medial part of its length showed annual rings (Fig. 4A). It has a caulinar origin because the distribution of the metaxylem and protoxylem (endarch primary xylem) (Fig. 4B). This caulinar part is constituted by secondary bark with notable cork (periderm). The secondary phloem presents abundant mechanical tissue, and the parenchyma cells of medullary rays are filled with crystals. Internal to vascular cambium it is the secondary xylem and the pith formed by parenchyma (Fig. 4A, C). Secondary xylem exhibits the growthrings, meaning the xylopodium development periods (Fig. 4A, D). Tyloses in vessels of the secondary xylem were found with tannin-filled vesicles (Fig. 4D, E). Phenolic compounds (tannins) were visualized by test of ferric chloride (Fig. 4F).

Root system. The cross-section of the taproot (the primary root) shows a secondary structure similar to stem (Fig. 5A), but may be seen with ample vessels of the metaxylem (exarch xylem) towards the centre; it has a tetrarch (Fig. 5B) or sometimes pentarch structure.

A taproot of 5-7 $\mathrm{mm}$ diameter, and root branches and adventitious root of $3 \mathrm{~mm}$ diameter were analyzed and presented a similar secondary structure with a periderm formed by 4-8 layers of cork (Fig. 5A; Fig. 6A, B). The cork cell walls embedded in suberin showed positive test for lipophilic substances. Internally, it is the cork-cambium (phellogen) produced from subepidermal layers, and one layer of phelloderm cells in contact with an ample area (10-14 layers) of cortical parenchyma (Fig. 6B). The most internal cortical layer is the endodermis, which presents Casparian strips and is surrounding the vascular cylinder (Fig. 6C, D). In the root cortex, in front of the secondary phloem joined to the endodermis are located the ducts (Fig. 6C). The secondary vascular cylinder showed the phloem with abundant mechanical tissue and dilated medullary rays characterized by the presence of abundant calcium oxalate crystals (Fig. 6C, D). Internal at vascular cambium the secondary xylem is found. As was mentioned above, the taproot shows tetrarch primary xylem in the centre (Fig. 5B), whereas, root branches and adventitious roots exhibit polyarch primary xylem, and lignified pith in the centre (Fig. $6 \mathrm{E})$. Root system has many branches, and the new roots are produced by a proliferation of the parenchyma tissue (Fig. 6F).

Roots histochemical tests revealed ducts containing resins and oil droplets (Fig. 7A-C). 


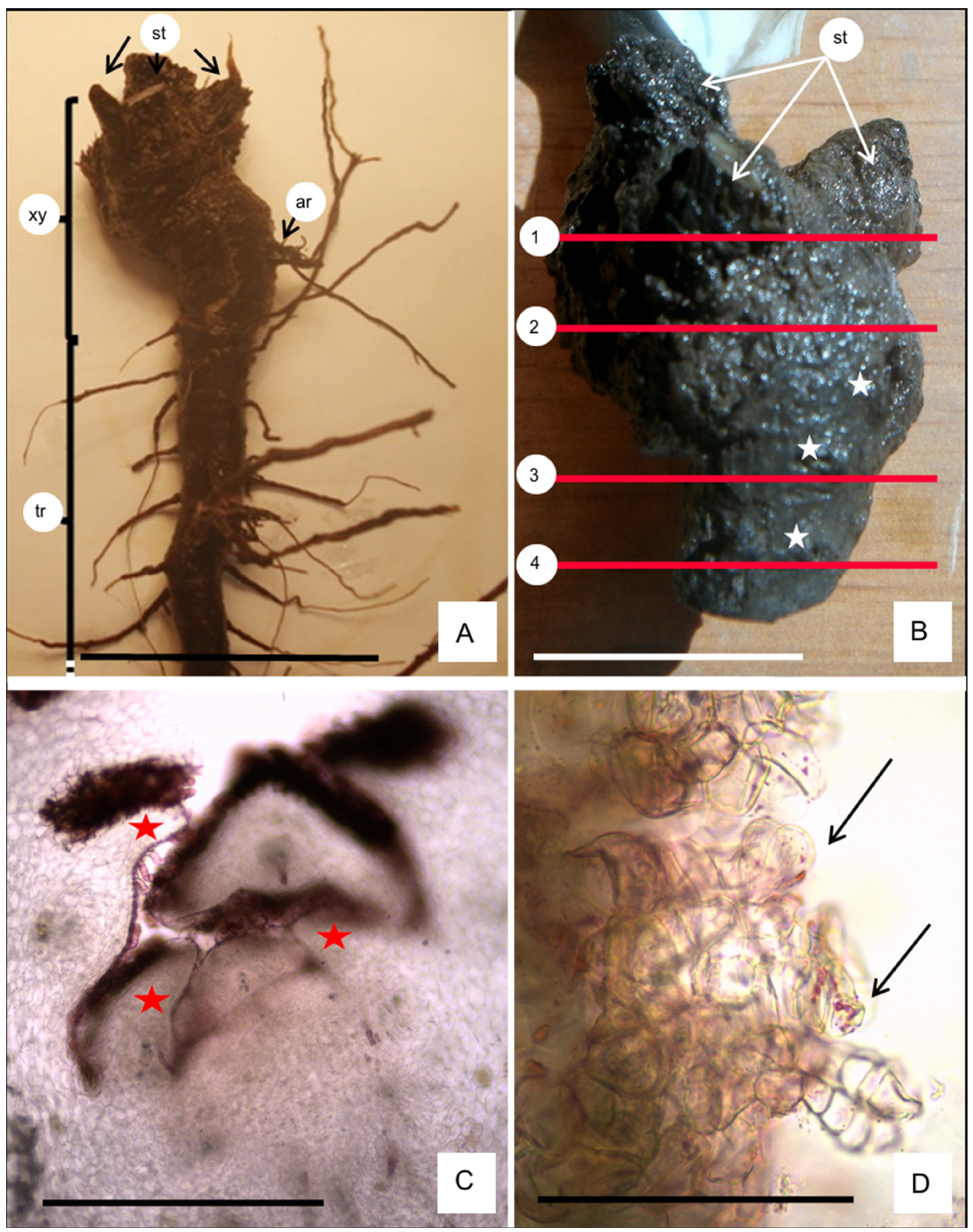

Fig. 2. Subterranean system of Baccharis notosergila. A: Xylopodium and root system. B: Detail of xylopodium showing three stems developed from yolks, and some buds (asterisks); 1, 2, 3, 4: indicate crosssections at stem, hypocotyl and taproot levels. C: An optical microscope view of a bud sectioned exhibiting several scale-leaf primordial (asterisks). D: Trichomes localized in the border of scale-leaf primordial, showing oil drops colored with Oil Red "O" (arrows). Scales=A: $5 \mathrm{~cm}$; B: $2 \mathrm{~cm}$; C, D: $100 \mu \mathrm{m}$. Abbreviations= ar: adventitious root; st: stems; tr: taproot with secondary branches; $x y: x y l o p o d i u m$. 

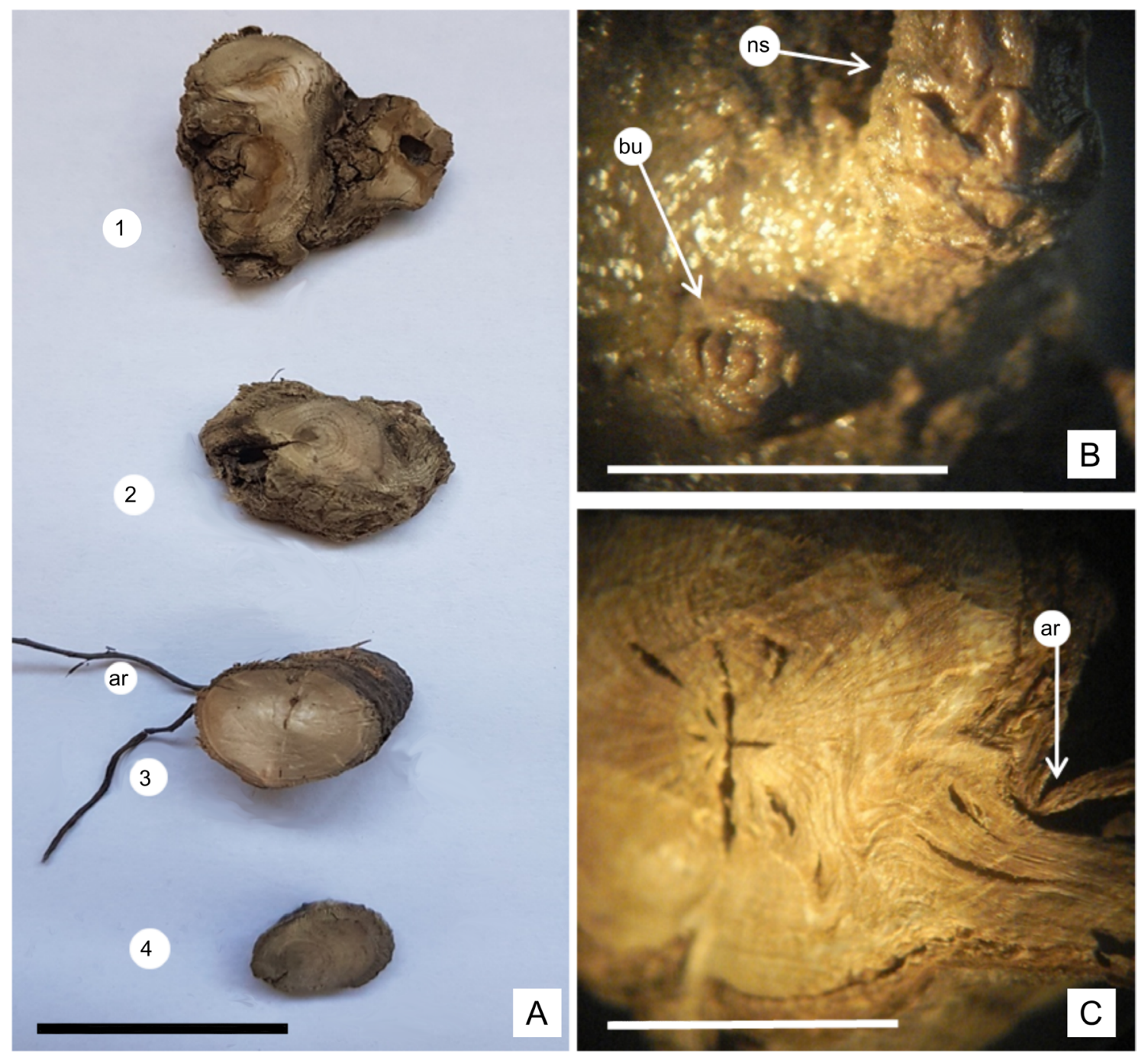

Fig. 3. Cross-sections of constitutent parts of xylopodium, buds and adventitious root of Baccharis notosergila. A: 1: Three aerial stems formed from the xylopodium buds. 2: Caulinar structure of xylopodium. 3: Hypocotyl or intermediate stem-root structure. 4: Taproot structure of xylopodium. B: A bud in surface view, showing scale-leaf primordial; at the top a new sprout developed with scale-leaves on its base. C: Cross-section exhibiting the adventitious root originated from the xylopodium. Scale= A: $2 \mathrm{~cm} ; \mathrm{B}, \mathrm{C}: 5 \mathrm{~mm}$. Abbreviations= ar: adventitious roots; bu: bud with scale-leaf primordial; ns: a new sprout.

The substance stored by roots was fructans of inulin-type located principally in the cortical parenchyma (Fig. 7D). Test for starch was negative.

In the xylopodium and roots, styloid calcium oxalate crystals were found (Fig. 6D). These styloids showed a tabular aspect with pointed and square ends (i. e., from lateral view they appeared fusiform, and from a frontal view as a table with truncate ends (Fig. 8A). These crystals sometimes appeared disposed in piles (Fig. 8B). A SEM-EDAX analysis showed they are 


\section{A. V. Carbone et al. - Baccharis notosergila: Subterranean system}
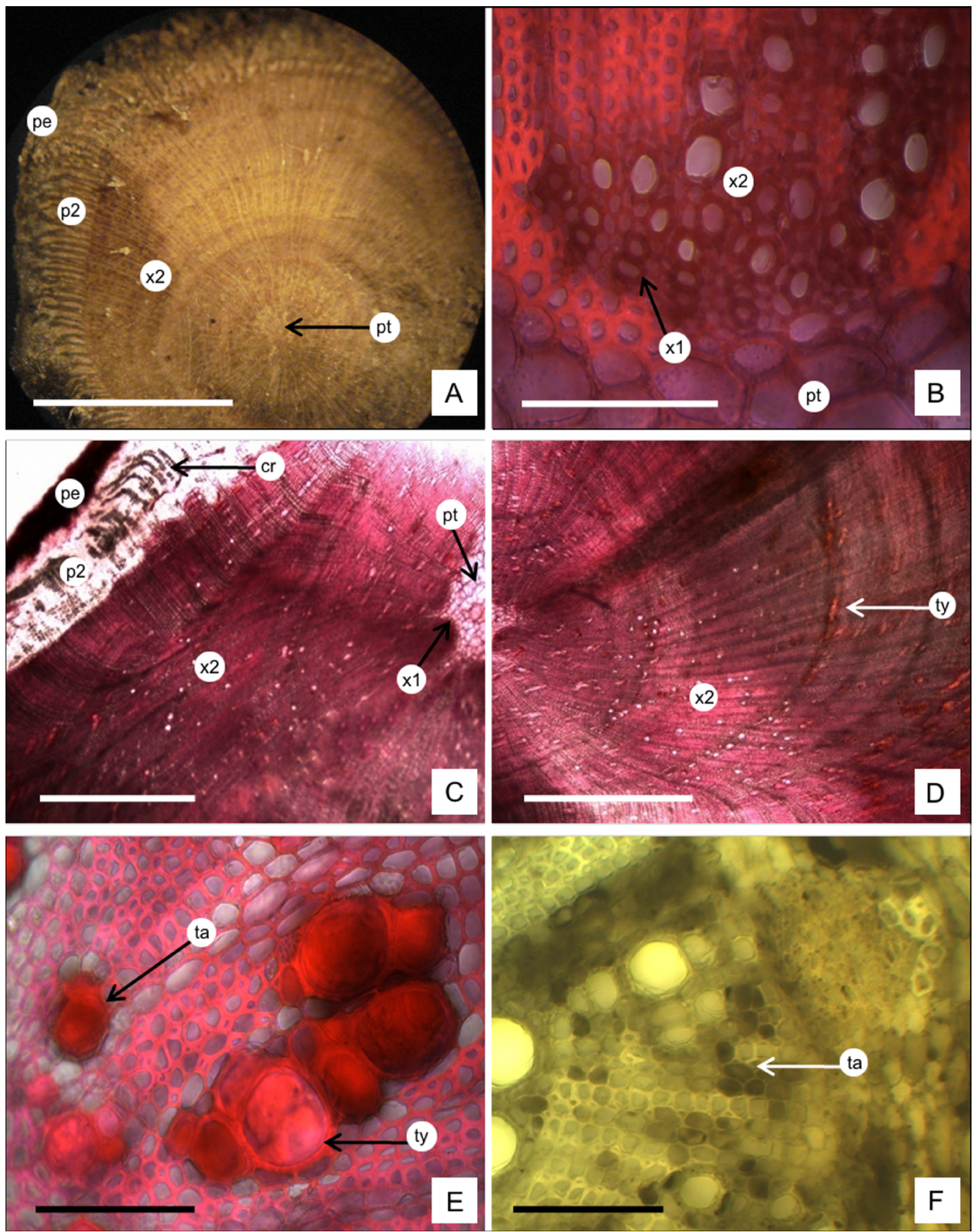

Fig. 4. Caulinar xylopodium features of Baccharis notosergila. A: Stem cross section showing external protection, periderm; secondary phloem with big quantity of crystals; secondary xylem with growth-rings surrounding the central pith. B: Stem central part, showing endarch xylem that means the caulinar origin. C: Microscopy cross section showing periderm, phloem, xylem and pith. D: Stem cross section exhibiting growth-rings and tyloses. E: Tyloses and tannins filling the vacuoles of cells. F: Test of tannins with ferric chloride. Scales= A: $5 \mathrm{~mm}$; B, E, F: $100 \mu \mathrm{m}$; C, D: $1 \mathrm{~mm}$. Abbreviations= cr: crystals; pe: periderm; p2: secondary phloem; pt: pith; ta: tannins; ty: tyloses; $\mathrm{x} 1$ : primary $\mathrm{xylem} ; \mathrm{x} 2$ : secondary $x y l e m$. 

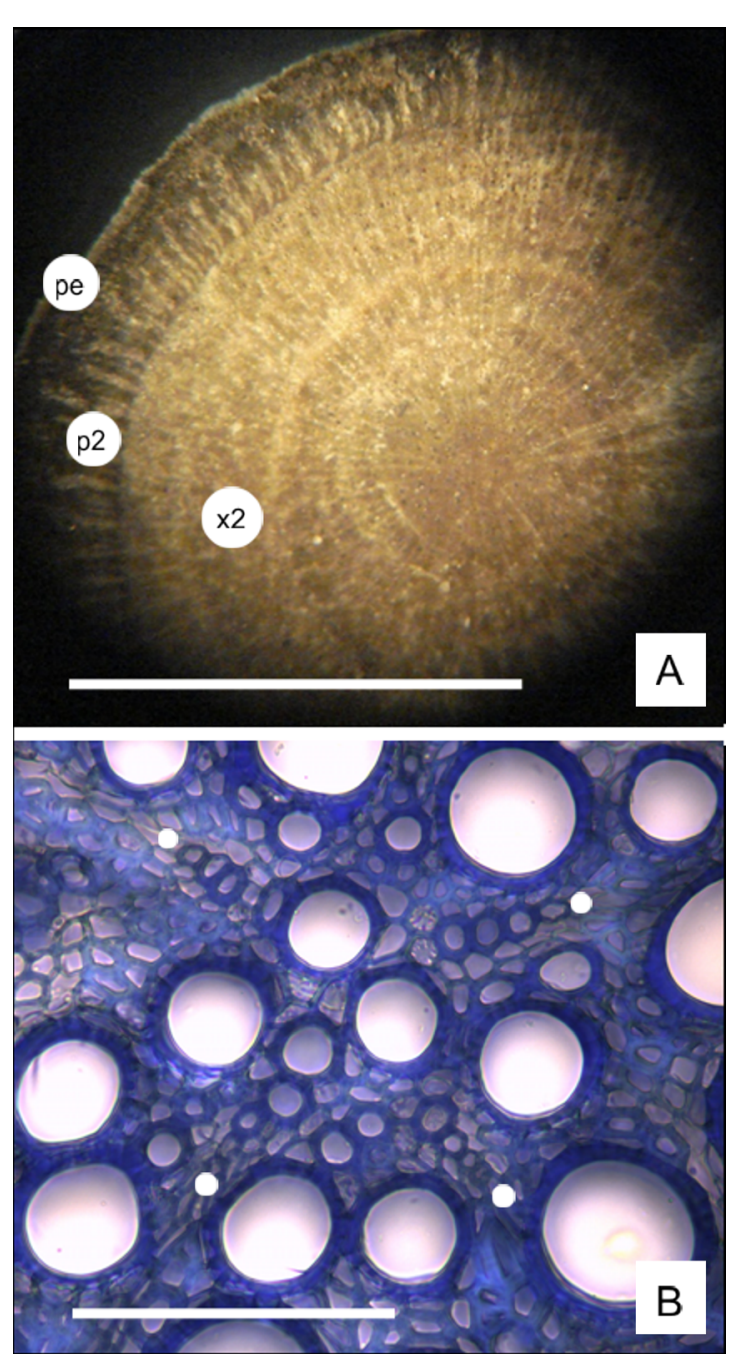

Fig. 5. Taproot features of Baccharis notosergila. A: Root tissues, growth-rings, and in secondary phloem may be seen radial dark strips that correspond to medullary rays filled with crystals. B: Tetrarch taproot showing the exarch primary xylem (white dots). Scales $=$ A: $5 \mathrm{~mm}$; B: $100 \mu \mathrm{m}$. Abbreviations= pe: periderm; $p 2$ : secondary phloem; $x 2$ : secondary xylem with annual rings.

composed predominantly of the cation calcium and sometimes a small quantity of potassium may also be found (Fig. 8C). Crystals were seen in dilated medullary rays of the phloem, and they are also abundant in the areas near buds formation.

\section{Discussion}

Baccharis notosergila showed a woody axis of xylopodium, which originates from the hypocotyl and exhibits caulinar and radicular structure as was found by Hayashi \& Appezzato-da-Glória (2007) in Vernonia grandiflora. The xylopodium studied is characterized by its buds production, as also seen in other species of Asteraceae (Appezzato-da-Glória et al., 2008a).

On the xylopodium, the primordial budleaves presented glandular and non-glandular trichomes. The presence of glandular trichomes in subterranean organs was previously recorded by Appezzato-da-Glória et al. (2008b), and also coincides with Appezzato-da-Glória et al. (2012) who studied the trichome structure and their secretory function in the species of Chrysolaena (Asteraceae). In B. notosergila were found uni and biseriate glandular trichomes and nonglandular uniseriate and flagelliform. The same trichomes types were described by Petenatti et al. (2007), Budel \& Duarte (2010), and Budel et al. (2015) for vegetative aerial parts of other species of the genus Baccharis. In the glandular and non-glandular trichomes, the cell walls stained positively for lipophilic compounds, however, the volatile oils are found in glandular trichomes as was reported by Budel et al. (2012).

In the xylopodium and roots calcium oxalate crystals filling the vacuole of cells were found. Cury (2008), studied the underground system of seven species of Asteraceae and mentioned only the presence of sclereids with a crystal in the xylopodium of Pterocaulon alopecuroides (Lam.) DC. The presence of calcium oxalate crystals of different types have been found in stems, cladodes, and leaves of Baccharis species (Cortadi et al., 1999; Petenatti et al., 2007; Budel \& Duarte, 2010; Jasinski et al., 2014; Budel et al., 2015; Bobek et al., 2015, 2016). In the subterranean organs, we found styloids similar to those reported by Budel et al. (2015) and Bobek et al. (2015, 2016). Bobek et al. (2016) mentioned that crystal shapes are one diagnostic characteristic for Baccharis species.

Baccharis notosergila presents a high number of multiseriate medullary rays in the roots. According to Metcalfe \& Chalk (1989), this 

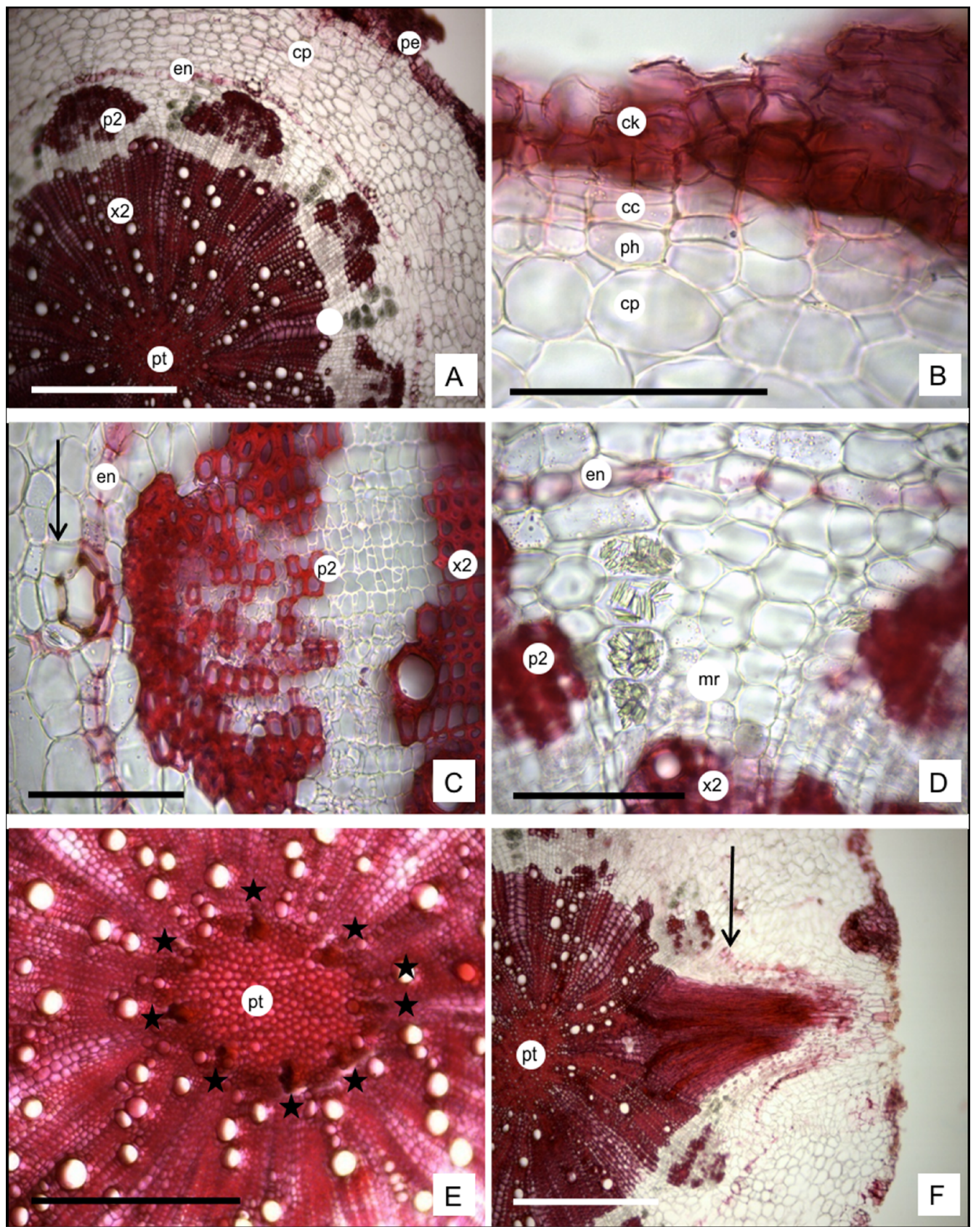

Fig. 6. Adventitious root features of Baccharis notosergila. A: Cross-section showing the tissues. B: Detail of root periderm exhibiting cork, phelogen and one layer of pheloderm outside the cortical parenchyma. C: Detail of root endodermis with a duct in front of secondary phloem (arrow); phloem showing abundant mechanical tissue. D: Secondary phloem showing dilated medullary ray and idioblast with crystals. E: Detail of root centre, showing poliarch primary xylem structure (asterisks), and lignified pith. F: A new root branch produced from a proliferation of parenchyma cells (arrow). Scales= A, E, F: $400 \mu \mathrm{m}$; B-D: $100 \mu \mathrm{m}$. Abbreviations= cc: cork cambium; ck: cork; $c p$ : cortical parenchyma; en: endodermis; mr: medullary ray; p2: secondary phloem; pe: periderm; ph: phelloderm; pt: pith; x2: secondary xylem. 
Bol. Soc. Argent. Bot. 54 (4) 2019
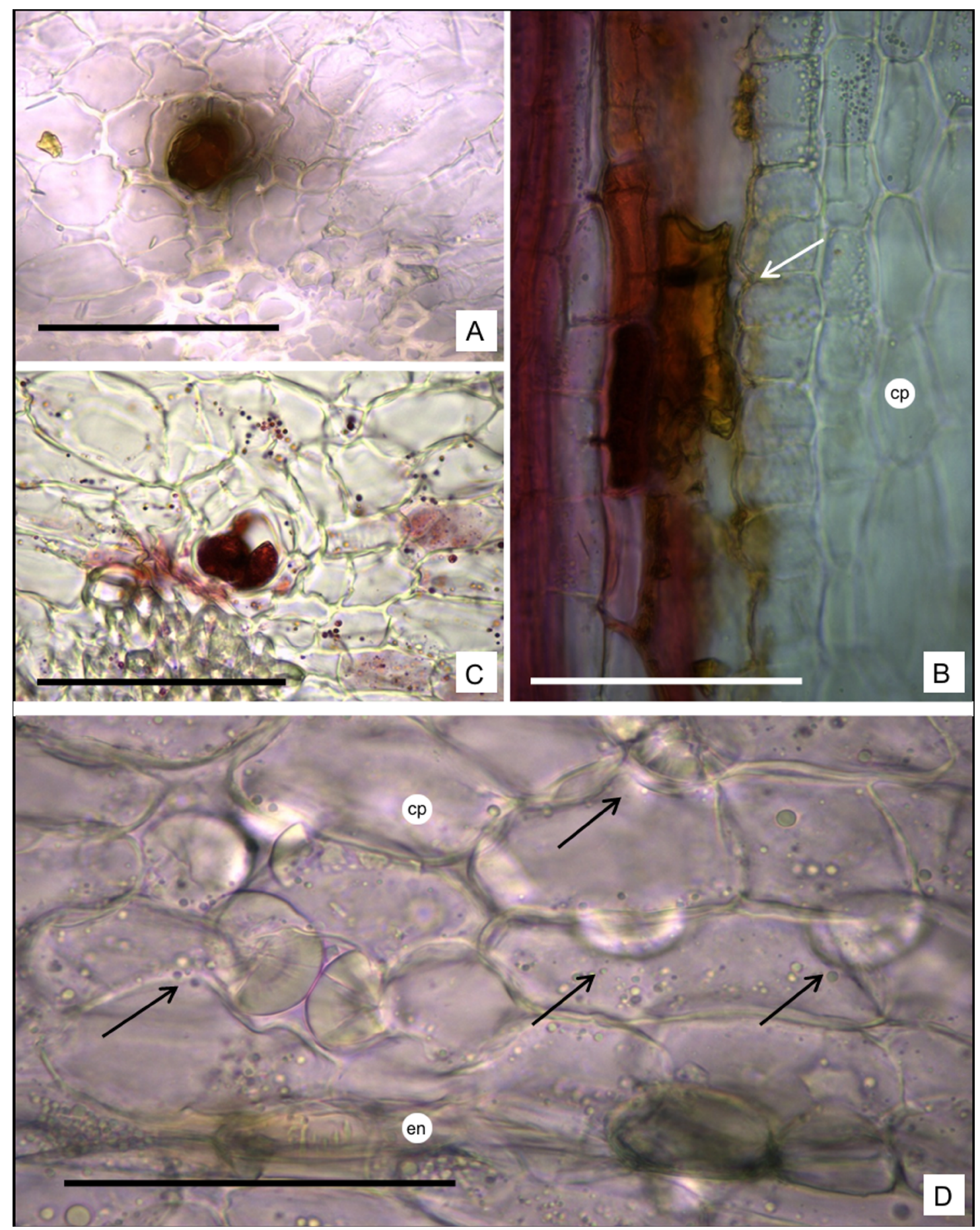

Fig. 7. Histochemical tests of Baccharis notosergila. A: Cross section of a duct containing resins (copper sulphate test). B: Longitudinal section of a duct showing resins (arrow). C: Another duct with resins inside and many oil small drops dispersed in the parenchyma (Oil red "O" test). D: Cortical parenchyma tissue showing spherocrystals of inulin (arrows). Scales $=$ A-D: $100 \mu \mathrm{m}$. Abbreviations $=\mathrm{cp}$ : cortical parenchyma; en: endodermis. 


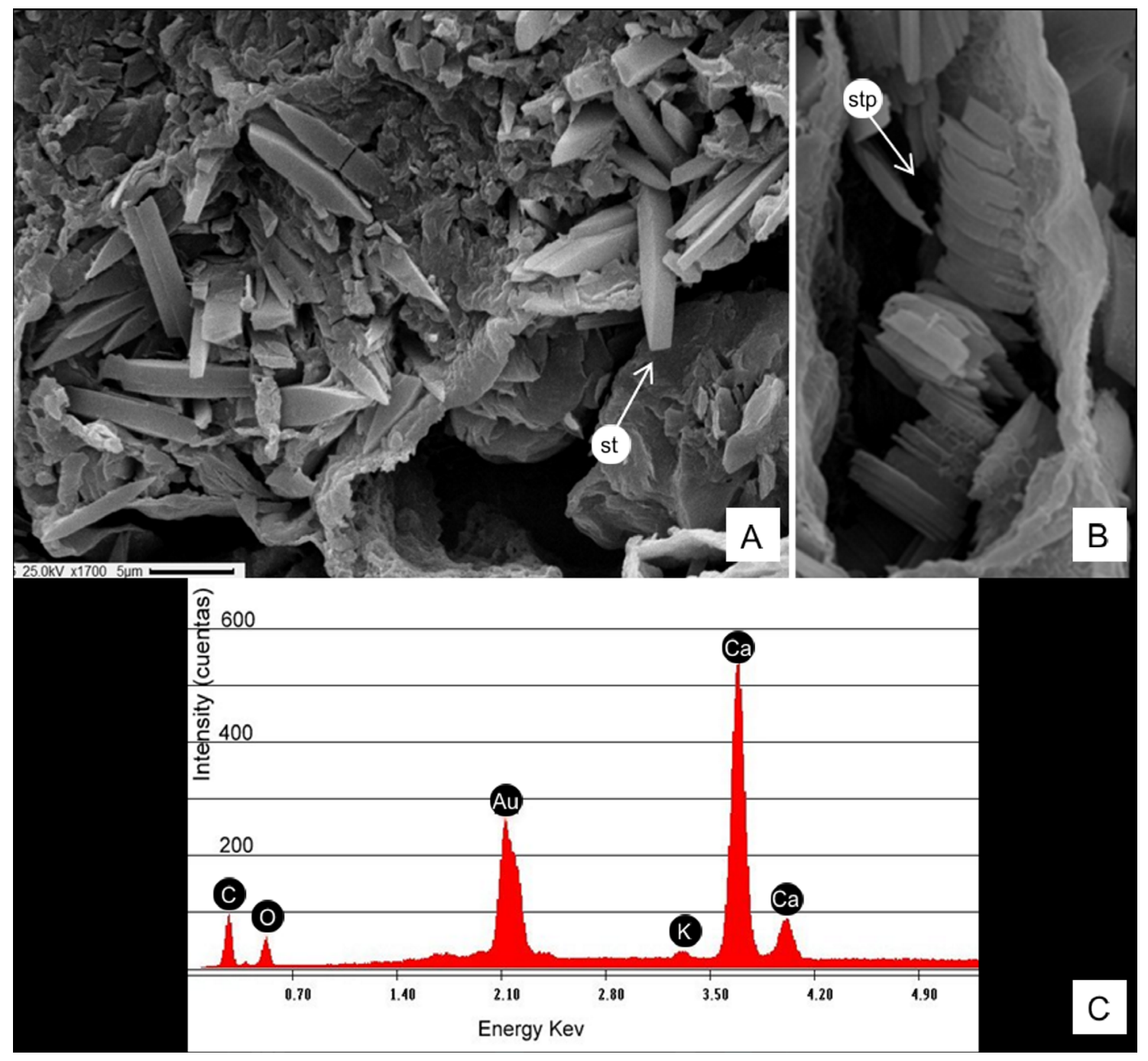

Fig. 8. Crystals and characteristic spectrum of the elements in parenchyma tissue of secondary phloem of Baccharis notosergila. A, B: Calcium oxalate crystals in xylopodium and root. A: styloids with pointed and truncate ends. B: styloids in piles. C: Characteristic spectrum of calcium and potassium ions. Scales= A, B: $5 \mu \mathrm{m}$. Abbreviations= st: styloid; stp: styloids in piles.

trait in roots might be attributed to increase the water transport function more than this reserve accumulation, coincidently inulin was not found in the rays. In secondary and adventitious roots, which grow more or less parallel to soil surface, we observed lignified pith and additionally abundant fibers in the secondary xylem. This root structural change would be mainly due to physiological causes such as the greater need to support function as suggested by Metcalfe \& Chalk (1989).

In the roots, chemical test for starch was negative, whereas was positive for inulin reserve. The inulin was found accumulated in the cortical parenchyma of the roots. It is the most frequent localization according to Hayashi \& Appezzato- 
da-Glória (2007) and Appezzato-da-Glória et al. (2008a). The carbohydrates play an important role in the plants growing in dry habitats because they may act as osmotic regulators due to their rapid polymerization and depolymerization abilities (Figueiredo-Ribeiro et al., 1991; FigueiredoRibeiro, 1993; Orthen, 2001; Gomes de Moraes et al., 2016). Baccharis notosergila is a resistant plant to stress conditions as drought and wet periods which alternate in the Salado river basin. It presents a xylopodium with buds, and the roots which accumulate carbohydrate reserves. It is in agreement with Hayashi \& Appezzato-daGlória (2007) and Appezzatto-da-Glória \& Cury (2011) who found that these two factors enabled the plants to survive through unfavourable environmental conditions. According preliminary assays to control $B$. notosergila populations mentioned above, we believe that these two traits allow to regeneration after mechanical and chemical control, assuring its survival.

\section{Conclusion}

The formation of aerial shoot from buds located in underground structures associated to the accumulation of fructans reinforces the importance of a viable underground bud bank for the persistence of this woody subshrub, and the difficulty found to mechanical and chemical control.

\section{AUTHOR CONTRIBUTION}

AVC provided the global research ideas and goals, and with FEF, provided of resources. MPH and AMA carried out the research, and AMA prepared the manuscript. All the authors have read the final manuscript and approved its submission.

\section{ACKNOWLEDgements}

We thank the technicians Mario Sánchez and Mariela Theiller of the electron microscope service CINDECA-CONICET-UNLP. Our acknowledgements to anonymous reviewers who contributed with suggestions and bibliography to improve the manuscript.

\section{BiBLIOGRAPHY}

ALONSO, A. A. \& S. R. MACHADO. 2007. Morphological and developmental investigations of the underground system of Erythroxylum species from Brazilian cerrado. Aust $J$ Bot 55: 749-758. https://doi.org/10.1071/BT07060

APPEZZATO-DA-GLÓRIA, G. \& G. CURY. 2011. Morpho-anatomical features of underground systems in six Asteraceae species from the Brazilian Cerrado. An. Acad. Bras. Ciênc. 83: 981-991. http://www. redalyc.org/articulo.os?id=32719268017 [Accesed: 2019 april].

APPEZZATO-DA-GLÓRIA, B., G. CURY, M. K. M. SOARES, R. ROCHA \& A. H. HAYASHI. 2008a. Underground systems of Asteraceae species from the Brazilian Cerrado. J. Torrey Bot. Soc. 135: 103-113. https://www.jstor.org/stable/20063964

APPEZZATO-DA-GLÓRIA, B., A. H. HAYASHI, G. CURY, M. K. M. SOARES \& R. ROCHA. 2008b. Occurrence of secretory structures in underground systems of seven Asteraceae species. Bot. J. Linnean Soc. 157: 789-796. https://doi.org/10.1111/j.1095-8339.2008.00823.x

APPEZZATO-DA-GLÓRIA，B., F. BATISTA DA COSTA, V. C. da SILVA, L. GOBBO-NETO, V. L. GARCIA REHDER \& A. H. HAYASHI. 2012. Glandular trichomes on aerial and underground organs in Chrysolaena species (VernonieaeAsteraceae): structure, ultrastructure and chemical composition. Flora 207: 878-887. http://dx.doi.org/10.1016/j.flora.2012.10.003

BOBEK, V. B., V. P. DE ALMEIDA, C. B. PEREIRA, G. HEIDEN, M. R. DUARTE, J. M. BUDEL \& T. NAKASHIMA. 2015. Comparative pharmabotanical analysis of Baccharis caprariifolia DC. and B. erioclada DC. From Campos Gerais, Paraná, Southern Brazil. Lat. Amer. J. Pharm. 34: 1396-1402.

BOBEK, V. B., G. HEIDEN, C. FREITAS DE OLIVEIRA, V. PAES DE ALMEIDA, J. PADILHA DE PAULA, P. V. FARAGO, T. NAKASHIMA \& J. M. BUDEL. 2016. Comparative analytical micrographs of "vassouras" (Baccharis, Asteraceae). Rev.. Bras. Farmacogn. 26: 665-672. http://dx.doi.org/10.1016/j.bjp.2016.05.001

BUDEL, J. M. \& M. R. DUARTE. 2010. Macro and microscopic characters of the aerial vegetative organs of carqueja: Baccharis usterii Heering. Braz. Arch. Biol. Technol. 53: 123-131. 


\section{A. V. Carbone et al. - Baccharis notosergila: Subterranean system}

BUDEL, J. M., M. R. DUARTE, P. M. DÖLLBOSCARDIN, P. V. FARAGO, N. I. MATZENBACHER, A. SARTORATTO \& B. H. L. N. SALES MAIA. 2012. Composition of essential oils and secretory structures of Baccharis anomala, B.megapotamica and B. ochracea. J. Essent. Oil Res. 24: 19-24. https://doi.org/10.1080/10412905.2012.645634

BUDEL, J. M., J. PADILHA DE PAULA, V. L. PEREIRA DOS SANTOS, C. R. CAVICHIOLO FRANCO, P. V. FARAGO \& M. R. DUARTE. 2015. Pharmacobotanical study of Baccharis pentaptera. Rev. Bras. Farmacogn. 25: 314-319. http://dx.doi.org/10.1016/j.bjp.2015.07.007

CORTADI, A., O. DI SAPIO, J. MC CARGO, A SCANDIZZI, S. GATTUSO \& M. GATTUSO. 1999. Anatomical studies of Baccharis articulata, Baccharis crispa and Baccharis trimera, "carquejas" used in folk medicine. Abbreviation Pharm. Biol. 37: 357-365. doi: 10.1076/phbi.37.5.357.6054

COSA, M. T., N. DOTTORI, L. STIEFKENS, M. HADID, M. MATESEVACH, N. DELBÓN, P. WIEMER, S. MACHADO, V. CABRERA, C. COSTA, A. PÉREZ \& A. TRENCHI. 2014. Aplicación de técnicas de histología vegetal a la resolución de diversos problemas. Laboratorio de Morfología Vegetal, Universidad Nacional de Córdoba.

CURY, G. 2008. Sistemas subterráneos de Asteraceae do Cerrado paulista: abordagens anatómica, ecológica e reproductiva. Tese Doutorado, Universidade de São Paulo, Escola Superior de Agricultura "Luiz de Queiroz", Piracicaba, Brazil, 95 pp.

D’AMBRogiO A. 1986. Manual de técnicas en histología vegetal. Hemisferio Sur, Buenos Aires, Argentina.

FIGUEIREDO-RIBEIRO, R. C. L. 1993. Distribuição, aspectos estruturais e funcionais dos frutanos, com ênfase em plantas herbáceas do Cerrado. Rev. Bras. Fisiol. Veg. 5: 203-208.

FIGUEIREDO-RIBEIRO, R. C. L., E. M. ISEJIMA, G. M. DIAS-TAGLIACOZZO, M. A. M. CARVALHO \& S. M. C. DIETRICH. 1991. The physiological significance of fructan accumulation in Asteraceae from the Cerrado. Cienc. Cult. 43: 443-446.

GOMES DE MORAES, M., M. A. MACHADO DE CARVALHO, A. C. FRANCO, C. J. POLLOCK \& R. DE CÁSSIA LEONE FIGUEIREDO-RIBEIRO. 2016. Fire and drought: soluble carbohydrate storage and survival mechanisms in herbaceous plants from the Cerrado. BioSience 66: 107-117.
GURR, E. 1971. Synthetic dyes in biology, medicine and chemistry. Academic Press, London.

HAYASHI, A. H. \& B. APPEZZATO-DA-GLÓRIA. 2007. Anatomy of the underground system in Vernonia grandiflora Less. and $V$. brevifolia Less. (Asteraceae). Braz. Arch. Biol. Technol. 50: 979-988. http://dx.doi.org/10.1590/S1516-89132007000700009

HERBICIDE RESISTANT PLANTS COMMITTEE. 1998. "Herbicide resistance" and "herbicide tolerance" defined. Weed Technol. 12: 789.

JASINSKI, V. C. G., R. Z. DA SILVA, R. PONTAROLO, J. M. BUDEL \& F. R. CAMPOS. 2014. Morphoanatomical characteristics of Baccharis glaziovii in support of its pharmacobotany. Rev. Bras. Farmacogn. 24: 609-616.

JOHANSEN, D. A. 1940. Plant microtechnique. McGraw-Hill Book Company, New York.

LUQUE, R., H. C. SOUSA \& J. E. KRAUS. 1996. Métodos de coloração de Roeser (1972) -modificadoe Kropp (1972) visando a substituição do azul de astra por azul de alcião $8 \mathrm{GS}$ ou $8 \mathrm{GX} /$ Staining methods of modified Roeser (1972) and Kropp (1972), aiming at substituting the astra blue by alcian blue 8GS or 8GX. Acta Bot. Bras. 10: 199 - 212. http://dx.doi.org/10.1590/S0102-33061996000200001

METCALFE, C. R. \& L. CHALK. 1989. Anatomy of the Dicotyledons. Clarendon Press, Oxford.

ORTHEN, B. 2001. Sprouting of the fructan- and starchstoring geophyte Lachenalia minima: effects on carbohydrate and water content within the bulbs. Physiol. Plant. 113: 308-314. https//doi: 10.1111/j.1399-3054.2001.1130302.x

PETENATTI, E. M., M. E. PETENATTI, D. A. CIFUENTE, J. C. GIANELLO, O. S. GIORDANO, C. E. TONN \& L. A. DEL VITTO. 2007. Medicamentos herbarios en el Centro-Oeste Argentino. VI. Caracterización y control de calidad de dos especies de "carquejas": Baccharis sagittalis y B. triangularis (Asteraceae). Lat. Am. J. Pharm. 26: 201-208.

PURICELLI, E. \& D. TUESCA. 2005. Efecto del sistema de labranza sobre la dinámica de la comunidad de malezas en trigo y en barbechos de secuencias de cultivos resistentes a glifosato. Agriscientia 22: 69-78.

RODRIGUEZ, A \& E. JACOBO. 2012. Manejo de pastizales naturales para una ganadería sustentable en la Pampa Deprimida. Buenas prácticas para una ganadería sustentable de pastizal. Kit de extensión para las pampas y campos. FAUBA Editorial. 
RUZIN, S. E. 1999. Plant microtechnique and microscopy. University Press, Oxford.

SIONE, S., R. SABATTINI, S. LEDESMA, A. F. DORSCH \& C. FORTINI. 2006. Notas: Caracterización florística y estructural del estrato arbustivo de un monte en pastoreo (Las Garzas, Entre Ríos). Revista Cientifica Agropecuaria 10: 59-67.

TERTULIANO, M. F. \& R. C. L. FIGUEIREDORIBEIRO. 1993. Distribution of fructose polymers in herbaceous species of Asteraceae from the cerrado. New Phytol. 123: 741-749. https://doi.org/10.1111/j.1469-8137.1993.tb03785.x

URDAMPILLETA, J. I. 2019. Métodos de control poblacional de Baccharis notosergila Griseb.: maleza arbustiva de alta incidencia en la zona de la Pampa Deprimida. Tesis de grado, modalidad: intervención profesional, Facultad de Ciencias Agrarias y Forestales, Universidad Nacional de La Plata. Dirección: A. V. Carbone. Codirección: F. E. Fernández. Repositorio Institucional de la UNLP. Disponible en: http://sedici.unlp.edu.ar/ handle/10915/74210

YASUÉ, T. 1969. Histochemical identification of calcium oxalate. Acta Histochem. Cytochem. 2: 83-95.

ZARLAVSKY, G. E. (ed.). 2014. Histología vegetal: Técnicas simples y complejas. Sociedad Argentina de Botánica, Buenos Aires. 